\title{
Model Test on Motion Responses and Anchor Reaction Forces of an Articulated Tower-Type Buoy Structure in Waves
}

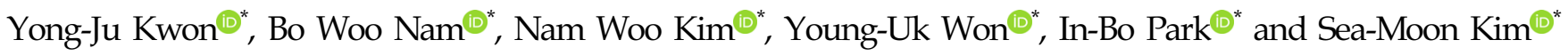 \\ "Korea Research Institute of Ships and Ocean Engineering, KRISO, Daejeon, Korea \\ 아티큘레이티드 타워 형태의 부이 구조물에 관한 \\ 파랑 중 운동응답 및 앵커 지지력에 관한 모형시험 연구

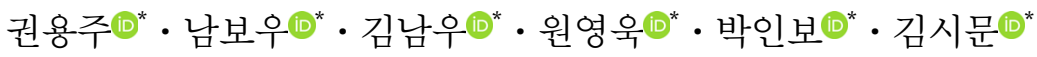 \\ "한국해양과학기술원 부설 선박해양플랜트연구소
}

KEY WORDS: Buoy structure 부이 구조물, Anchor force 앵커 지지력, Motion response 운동응답, Environmental loads 환경하중, Model test 모형시험

\begin{abstract}
A series of model tests was performed to evaluate the survivability of an articulated tower-type buoy structure under harsh environmental conditions. The buoy structure consisted of three long pipes, a buoyancy module, and top equipment. The scale model was made of acrylic pipe and plastic with a scale ratio of 1/22. The experiments were carried out at the ocean engineering basin of KRISO. The performance of the buoy structure was investigated under waves only and under combined environmental conditions from sea state (SS) 5 to 7. A nonlinear time-domain numerical simulation was conducted using the mooring analysis program OrcaFlex. The survivability of the buoy was analyzed based on three factors: the pitch motion, submergence of the top structure, and anchor reaction force. The model test results were directly compared to the results of numerical simulations. The effects of the sea state and combined environment on the performance of the buoy structure were investigated.
\end{abstract}

\section{1. 서 론}

우리나라 연안 및 근해에는 다양한 목적으로 다수의 부이들이 설치 운용되고 있다. 그 중 많은 수의 부이는 해양 관측용 부이 로써 해양환경 및 기타 데이터를 모니터링, 저장, 송신하기 위한 목적으로 사용된다. 이러한 해양 관측용 부이는 특정 위치에서 지속적인 데이터를 수집해야 하기 때문에, 다양한 계류방식을 이용하여 위치를 유지하는 기능을 갖는다. 계류 부이는 크게 한 점으로 계류된 일점계류부이(Single point moored buoy)와 다점으 로 계류된 다점계류부이(Multileg buoy)로 나누어 질 수 있으며 (Berteanx, 1976), 일점계류부이는 긴장계류(Taut mooring), 이완 계류(Catenary mooring), S자형 계류(Lazy wave mooring) 등으로 나눌 수 있다. 긴장계류는 계류위치 정밀도가 우수하나, 부이본 체의 침강이 일어날 수 있는 단점이 있다(Park and Shin, 2003). 기존의 부이에 대한 많은 연구들은 일점계류부이에 대한 파
랑 및 조류 중의 응답에 주로 집중되었다. Carpenter et al.(1995) 은 스파와 구 형상의 부이에 대한 불규칙파 중 시험연구를 수 행하였으며, 계류 케이블을 이용하여 긴장계류의 형태를 취하 였다. 그들은 스파 부이와 구형상의 부이의 6자유도 공진주파수 를 검토하였으며, 각 부이별 공진특성을 분석하였다. Ma et al.(2015)은 인장 계류 부이의 플로터의 운동에 대해 시간에 따 른 계류선장력의 변화와 더불어 Sub-harmonic 운동에 대해 검토 하였다. 인장식 계류 부이의 비선형 운동을 분석하고자 부이의 운동과 계류선 거동사이의 강한 연성효과를 포함한 수치모델을 구축하고, 시험과 수치해석 간의 결과를 비교하였다. 선형운동 뿐만 아니라 Sub-harmonic 운동 요소를 자세히 검토하였으며, Sub-harmonic 운동은 시간별로 변화하는 계류선의 장력에 의해 발생하는 비선형 연성 효과로 인해 지배됨을 확인하였다. Lee et al.(2014)은 5개의 부이 형상에 따른 계류선의 장력 변화를 검 토하였으며, 파랑 및 조류 조건에서 시험을 수행하였다. 계류선

Received 8 August 2018, revised 12 April 2019, accepted 13 June 2019

Corresponding author Bo Woo Nam: +82-42-866-3934, bwnam@kriso.re.kr ORCID: https://orcid.org/0000-0003-1125-7453

It is noted that this paper is revised edition based on proceedings of KSOE 2017 in Geoje

(C) 2019, The Korean Society of Ocean Engineers

This is an open access article distributed under the terms of the creative commons attribution non-commercial license (http://creativecommons.org/licenses/by-nc/3.0) which permits unrestricted non-commercial use, distribution, and reproduction in any medium, provided the original work is properly cited. 
의 장력 변화는 구조물의 단면적과 항력계수의 차이와 관계됨 을 확인하였다(Lee et al., 2014).

본 연구에서는 아티큘레이티드 타워(Articulated tower) 형태의 긴 파이프와 부력재로 구성된 세장형 부이 구조물의 황천 조건 에서의 생존성을 모형시험 연구를 통하여 평가하였다. 아티큘 레이티드 타워 형태의 부이 구조물은 통상적인 체인계류 방식 을 이용한 일점 계류부이와 달리 수면 하에 위치한 부력재를 이용하여 위치를 유지하는 방식이다. 부이 구조물의 성능 평가 를 위해 50년 재현주기 조건을 포함한 3 가지 해상상태에서 모 형시험을 수행하였고 종동요, 침수여부, 앵커 지지력에 대하여 분석하였다. 모형시험은 파도 단독 해상상태 및 복합 환경 해상 상태에서 수행되었으며, 모형시험 결과를 수치 시뮬레이션 결 과와 비교 분석하였다.

\section{2. 모형시험}

\section{1 시험 모형}

긴 파이프와 부력재로 구성된 세장형 아티큘레이티드 타워 형태의 부이 구조물의 황천 시 생존성(Survivability)을 모형시험 을 통하여 평가하였다. 대상 부이구조물은 Fig. 1과 같이 상부구 조물(Equipment) 아래로 파이프-부력재-파이프로 구성되며, 부이 끝단은 중력식 앵커로 지지된다. 부이 구조물 중앙에 위치한 주 판알 모양의 부력재는 추가 부력을 제공하여 전체 부이 구조물

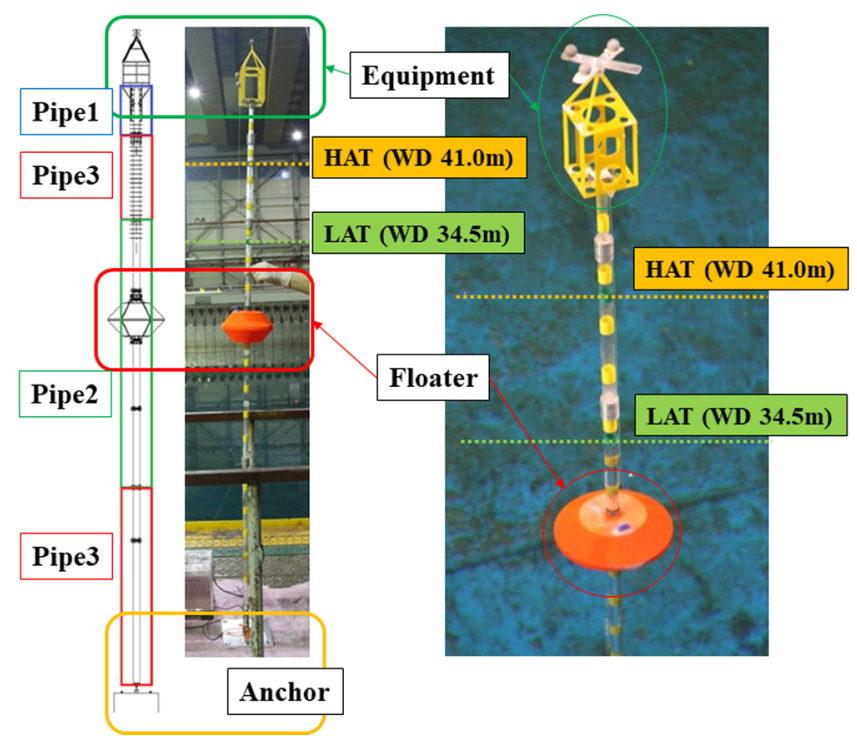

Fig. 1 Articulated tower-type buoy
Table 1 Main dimension of the upper structure and floater

\begin{tabular}{cccc}
\hline \hline Item & Unit & Proto & Model (1/22) \\
\hline Upper structure height & {$[\mathrm{m}]$} & 2.60 & 0.118 \\
Upper structure length & {$[\mathrm{m}]$} & 2.00 & 0.091 \\
Floater diameter & {$[\mathrm{m}]$} & 4.30 & 0.195 \\
Floater height & {$[\mathrm{m}]$} & 2.50 & 0.114 \\
Floater mass & {$[\mathrm{kg}]$} & 2820.0 & 0.265 \\
\hline
\end{tabular}

이 양성 부력을 유지하도록 하는 역할을 한다. 부이 전체의 지 지대 역할을 하는 파이프는 상부파이프(파란색 표시, Pipe 1), 부력재부 파이프(초록색 표시, Pipe 2), 상하부파이프(빨간색 표 시, Pipe 3)로 구분된다. 모형시험은 선박해양플랜트연구소(Korea Research Institute of Ships and Ocean Engineering, KRISO)의 해 양공학수조에서 수행되었다. 모형의 축척비는 $1 / 22$ 이며, 아크릴 파이프와 플라스틱을 조합하여 제작하였다. 상부구조물과 부력 재의 주요제원을 Table 1에 나타내었고, 파이프의 주요제원을 Table 2에 요약 제시하였다. 파이프의 내부를 방수하였다.

\section{2 환경조건}

Table 3은 모형시험에서 고려한 총 6가지의 환경조건을 보여 준다. IRW01 03은 해상상태 5에서 7까지의 파도 단독 조건이 며, IRW04 06은 같은 해상상태에서 파도, 바람, 조류가 모두 포 함된 복합 환경 조건이다. 이 때 해상상태 7은 설치대상해역인 서해에서 50년 재현주기(Return period)에 해당하는 불규칙파 해 상상태에 대응된다. 본 연구에서 고려한 바람과 조류의 속도는 각각 $50 \mathrm{~m} / \mathrm{s}$ 와 $2 \mathrm{~m} / \mathrm{s}$ 이며, 이는 태풍 시의 바람 속도와 서해의 강 한 조류 속도를 고려하여 설정된 값이다. 본 부이 구조물은 방 향성이 없으므로 선수파 조건만을 고려하였으며, 모든 경우 파 도와 같은 방향(Collinear)으로 조류와 바람이 작용하는 조건으 로 가정하여 시험을 수행하였다. 본 연구에서는 JONSWAP(Joint North Sea wave project) 스펙트럼이 사용되었다. Fig. 2는 대상 파도 스펙트럼과 계측된 파도 스펙트럼을 비교하여 보여주고 있다. 빨간색 실선은 대상 파도 스펙트럼을 나타내며, 검정색 점선은 모형시험에서 생성된 파도 스펙트럼이다. 조파성능의 한계로 인하여 해상상태 7의 경우 정점주기와 파 에너지가 다 소 차이나는 것을 볼 수 있지만, 유의파고 기준으로 $10 \%$ 이내 로 교정된 파도 스펙트럼이 본 시험에 적용되었다. 해상상태에 따라 파도 스펙트럼을 비교하면, 해상상태가 커짐에 따라 파랑 에너지가 크게 증가하고 정점 주기는 점차 장주기(저주파수) 쪽 으로 이동하는 것을 확인할 수 있다.

Table 2 Main dimension of the articulated tower-type buoy

\begin{tabular}{cccccccc}
\hline \hline \multirow{2}{*}{ Item } & Unit & \multicolumn{3}{c}{ Proto } & \multicolumn{3}{c}{ Model $(1 / 22)$} \\
\cline { 3 - 8 } & & Pipe 1 & Pipe 2 & Pipe 3 & Pipe 1 & Pipe 2 & Pipe 3 \\
\hline Outer diameter & {$[\mathrm{m}]$} & 0.4064 & 0.508 & 0.508 & 0.018 & 0.023 & 0.023 \\
Inner diameter & {$[\mathrm{m}]$} & 0.378 & 0.458 & 0.4796 & 0.017 & 0.021 & 0.022 \\
EA & {$[\mathrm{kN}]$} & $3.71 \mathrm{E}+06$ & $8.04 \mathrm{E}+06$ & $4.67 \mathrm{E}+06$ & 348.348 & 755.275 & 438.588 \\
EI & {$\left[\mathrm{kN} \cdot \mathrm{m}^{2}\right]$} & $7.14 \mathrm{E}+04$ & $2.35 \mathrm{E}+05$ & $1.42 \mathrm{E}+05$ & 0.014 & 0.046 & 0.028 \\
Length & {$[\mathrm{m}]$} & 2.94 & 20.372 & $7.0 / 13.95$ & 0.134 & 0.926 & $0.318 / 0.634$ \\
\hline
\end{tabular}


Table 3 Environmental conditions

\begin{tabular}{|c|c|c|c|c|c|c|c|c|c|c|c|c|}
\hline \multirow{3}{*}{ Wave ID } & \multirow{3}{*}{$\begin{array}{l}\text { Dir. } \\
\text { [deg] }\end{array}$} & \multicolumn{3}{|c|}{ Proto } & \multirow{3}{*}{$\begin{array}{l}\text { Current vel. } \\
\qquad[\mathrm{m} / \mathrm{s}]\end{array}$} & \multirow{3}{*}{$\begin{array}{l}\text { Wind. vel. } \\
\qquad[\mathrm{m} / \mathrm{s}]\end{array}$} & \multicolumn{3}{|c|}{ Model $(1 / 22)$} & \multirow{3}{*}{$\begin{array}{l}\text { Current vel. } \\
\qquad[\mathrm{m} / \mathrm{s}]\end{array}$} & \multirow{3}{*}{$\begin{array}{l}\text { Wind. vel. } \\
\qquad[\mathrm{m} / \mathrm{s}]\end{array}$} & \multirow{3}{*}{$\begin{array}{c}\text { Env. } \\
\text { Remark } \\
{[-]}\end{array}$} \\
\hline & & $T p$ & $H s$ & $\gamma$ & & & $T p$ & $H s$ & $\gamma$ & & & \\
\hline & & {$[\mathrm{s}]$} & {$[\mathrm{m}]$} & {$[-]$} & & & {$[\mathrm{s}]$} & {$[\mathrm{m}]$} & {$[-]$} & & & \\
\hline IRW01 & 180 & 9.70 & 3.25 & 3.3 & - & & 2.07 & 0.15 & 3.3 & - & & Sea state 5 \\
\hline IRW02 & 180 & 12.40 & 5.0 & 3.3 & - & & 2.64 & 0.23 & 3.3 & - & & Sea state 6 \\
\hline IRW03 & 180 & 15.4 & 8.0 & 3.3 & - & & 3.28 & 0.36 & 3.3 & - & & Sea state 7 \\
\hline IRW04 & 180 & 9.70 & 3.25 & 3.3 & 2.0 & 50.0 & 2.07 & 0.15 & 3.3 & 0.43 & 10.33 & Sea state 5 \\
\hline IRW05 & 180 & 12.40 & 5.0 & 3.3 & 2.0 & 50.0 & 2.64 & 0.23 & 3.3 & 0.43 & 10.33 & Sea state 6 \\
\hline IRW06 & 180 & 15.4 & 8.0 & 3.3 & 2.0 & 50.0 & 3.28 & 0.36 & 3.3 & 0.43 & 10.33 & Sea state 7 \\
\hline
\end{tabular}
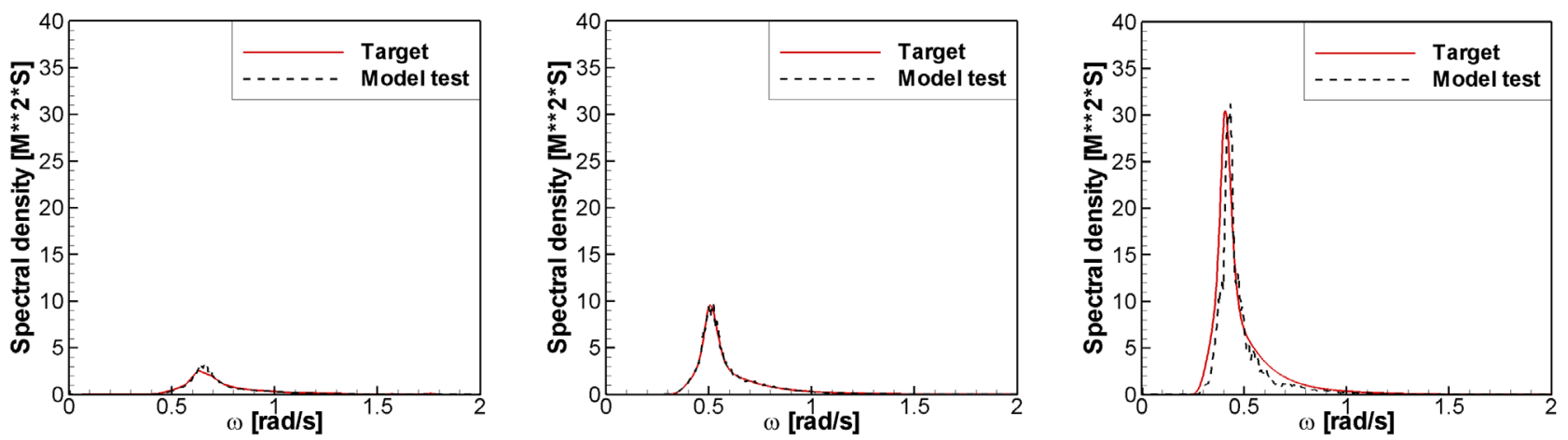

Fig. 2 Wave spectra (left: sea state 5, middle: sea state 6, right: sea state 7)

\section{3 수조 배치 및 계측 항목}

Fig. 3은 모형시험 시 수조 내의 배치와 계측 항목을 도시하 여 보여준다. 축척비를 고려하였을 때 해양공학수조의 수심이 대상해역의 수심보다 깊기 때문에, 대상 부이 구조물의 하단에 는 바닥 구조물을 설치하였다. 바람을 발생하기 위하여 구조물 전방 $5 \mathrm{~m}$ 지점에 바람 발생 장치 2 기를 설치하여 운용하였다. 이 때 바람 발생 장치는 파도와 조류의 방향과 동일하게 바람 이 생성될 수 있도록 설치하였다. 모형시험 시 계측항목으로는 부이 구조물 운동(종동요)과 앵커 지지력이 있으며, 거동 특성 과 침수 여부를 확인하기 위하여 비디오 촬영을 진행하였다. 본 시험에서 부이 구조물 운동은 Fig. 1과 같이 상부 구조물 최상
단에 3 개의 마커를 부착하고, 비접촉식 광학 운동 계측 카메라 (Qualisys)를 이용하여 운동 계측을 수행하였다. 앵커 지지력은 바닥 구조물과 부이 구조물 사이에 1축 방수 로드셀을 연결하 여 계측하였으며, 수직방향의 하중을 계측하였다. 비디오 촬영 을 위해 수상과 수중 카메라를 설치하여 부이 구조물의 운동과 침수여부를 확인하였다.

\section{3. 수치 시뮬레이션}

서해에 설치된 부이에 대한 거동 해석을 위해 상용 계류해석 프로그램인 OrcaFlex를 이용하였다. 상부구조물와 부력재의 모
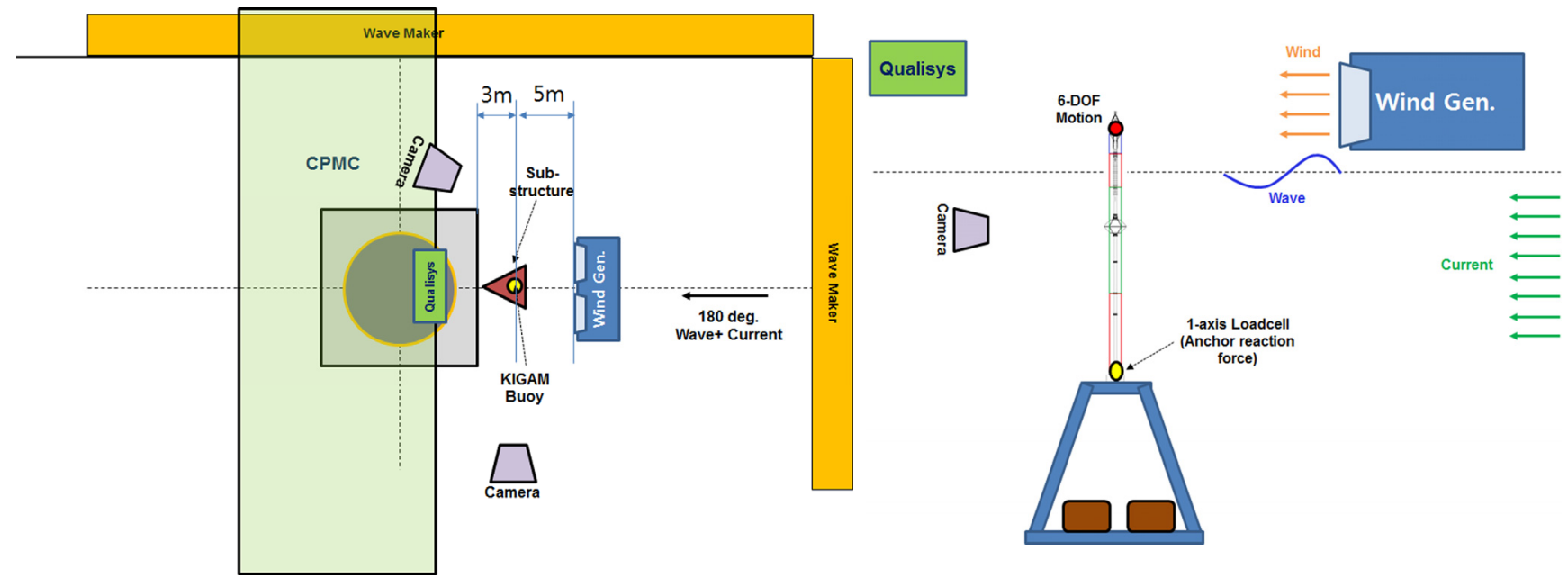

Fig. 3 Experimental set-up \& measurement 


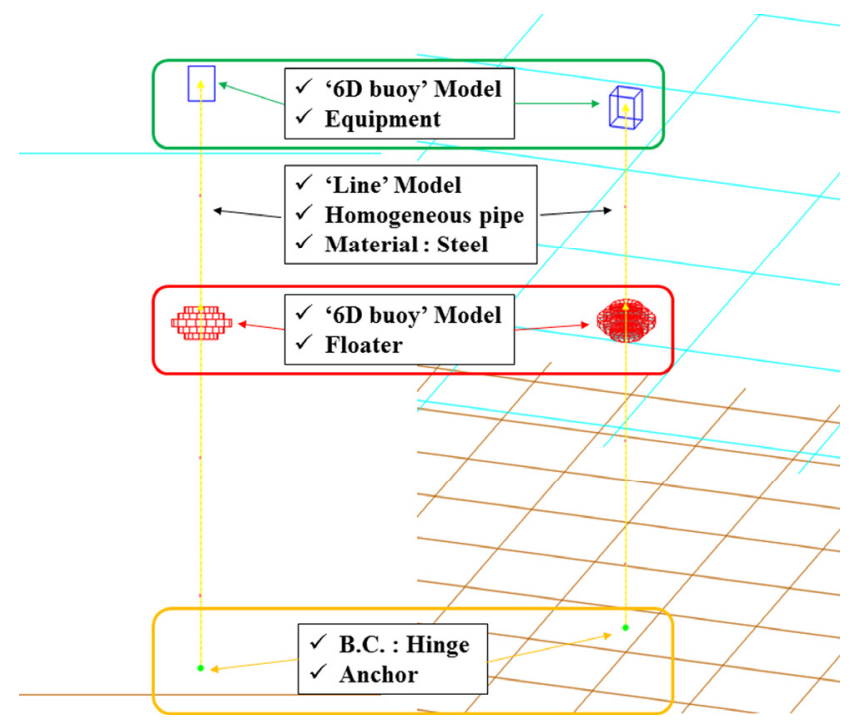

Fig. 4 Simulation model (left: side view, right: bird view)

델링은 OrcaFlex 내의 ‘6D buoy’ 모델을 이용하여 관성력과 부 력, 유체항력을 외력으로 고려하였다. 이 때, 유체력 계산은 모 리슨(Morison) 방정식을 이용하고, 항력계수 및 부가질량 계수 는 1.0 을 적용하였다. 외/내경이 서로 다른 3 종류의 파이프는 'Steel' 재질의 'Homogeneous pipe'로 모델링하였다. 항력계수 및 부가질량계수는 각각 1.2 와 1.0 을 사용하였다. 또한 파이프의 하 부 경계조건은 힌지로 고려하였다. 파랑, 조류, 바람 등의 해양 환경하중에 의해 구조물 응답이 발생하며, 응답특성을 반영하
기 위해 굽힘 강성(Bending stiffness, EI) 등을 고려하였다. 파이 프의 무게 보정을 위해 'Clump'모델을 이용하였다. Fig. 4는 OrcaFlex에서 사용한 수치 모델을 도식적으로 보여주며, 모든 수치 시뮬레이션은 실선 스케일로 계산을 수행하였다.

\section{4. 결과 및 고찰}

\section{1 종동요 응답}

본 부이 구조물은 앵커와 힌지 연결되어 있기 때문에, 환경외 력에 의해 앵커 연결점을 중심으로 회전운동을 하게 된다. 선수 파 조건에서는 부이 구조물의 종동요 응답이 발생하며, 응답은 상부구조물의 침수, 앵커 하중, 파이프의 구조 응력을 유발한다. Fig. 5는 모형시험 시 부이 구조물의 수상 및 수중 거동 모습을 보여준다. 구조물이 종동요 운동에 의해 파이프의 흘수가 크게 변하고, 상부구조물과 수면사이의 수직 거리도 시시각각 변화 된다.

Fig. 6은 부이 구조물의 종동요 운동 시계열이며, 3 가지 해상 상태에서의 파도 단독 조건(왼쪽)과 복합 환경 조건(오른쪽) 결 과이다. 파도 단독 조건에서 종동요 운동은 $0^{\circ}$ 를 기준으로 발생 하지만, 복합 환경 조건에서는 조류 및 바람에 의한 정적하중으 로 인하여 약 $14^{\circ}$ 를 기준으로 동적 응답이 발생한다. 해상 상태 가 높아짐에 따라 파도 에너지가 증가하며, 부이 구조물의 종동 요는 해상상태가 높아짐에 따라 크게 증가하는 경향을 보인다. 부이의 종동요는 파도 단독 조건에서 복합환경 조건에 비해 더 크게 증가하는 경향을 보인다.
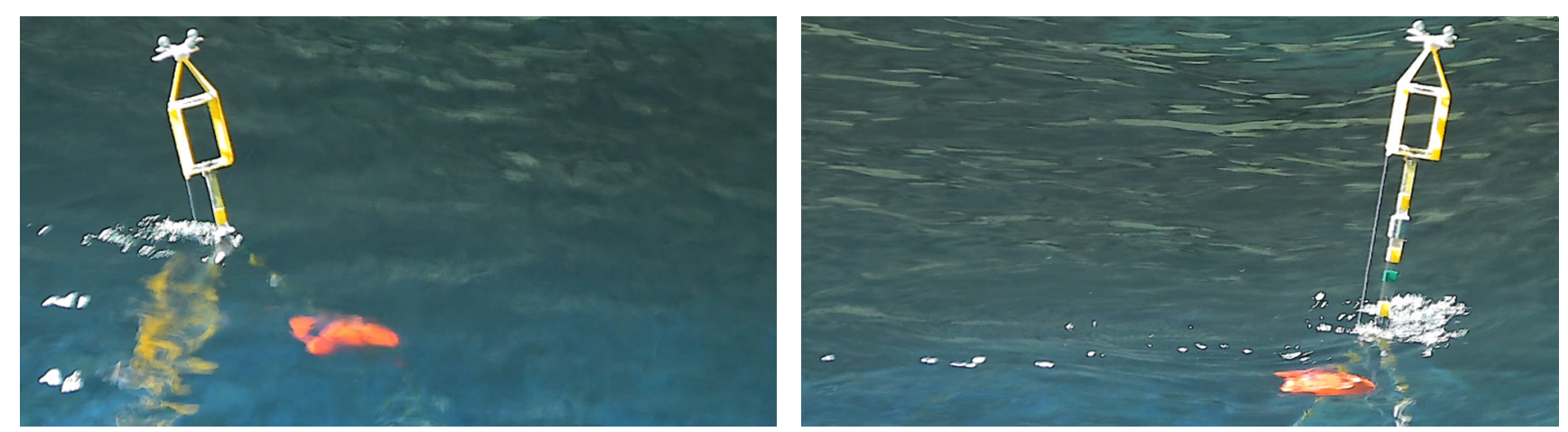

(a) Side view
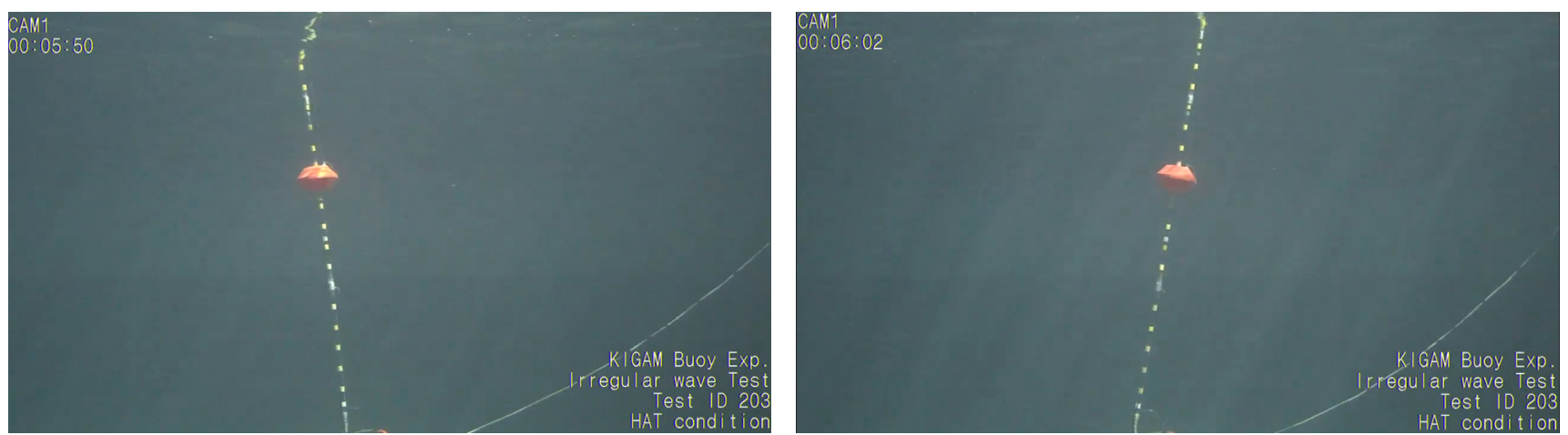

(b) Underwater view

Fig. 5 Snapshots on pitch angle in HAT condition 

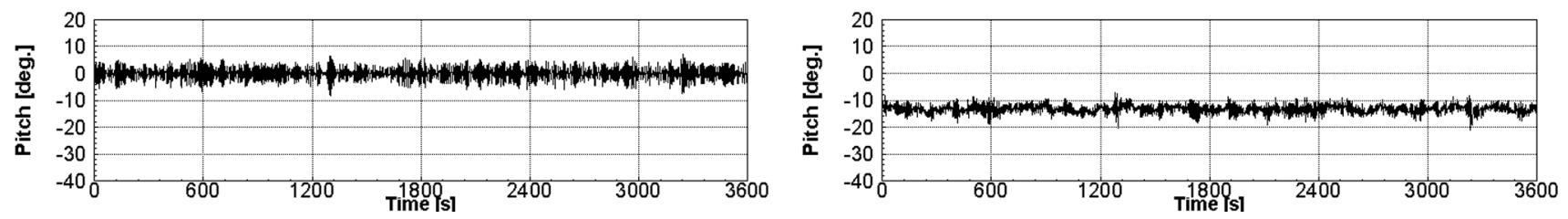

(a) Sea state 5
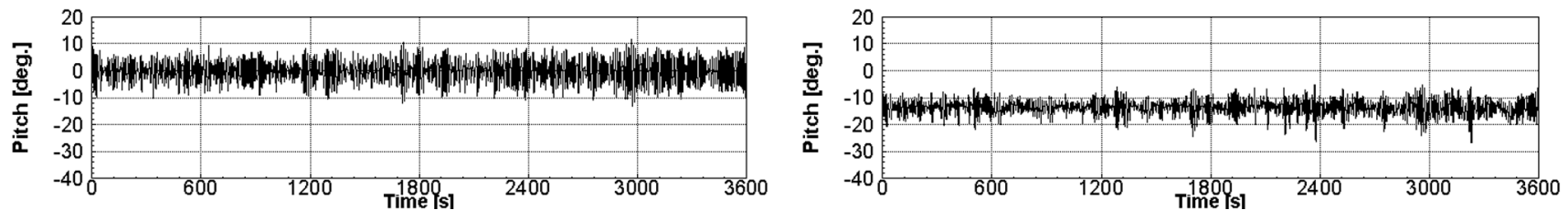

(b) Sea state 6
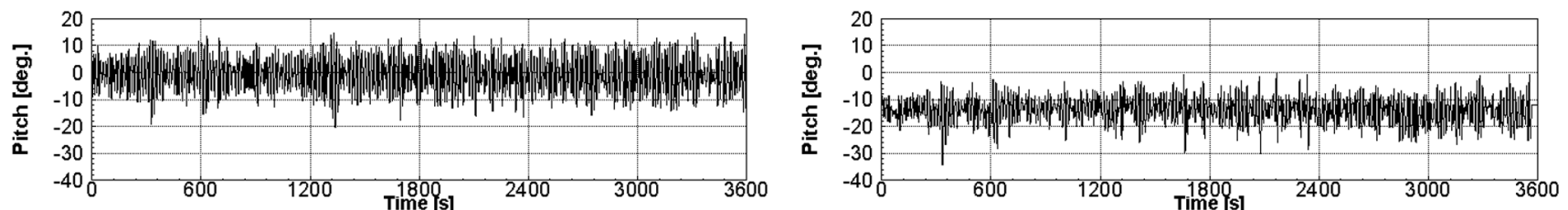

(c) Sea state 7

Fig. 6 Time series of pitch motion of the buoy (left: wave only, right: combined environment)
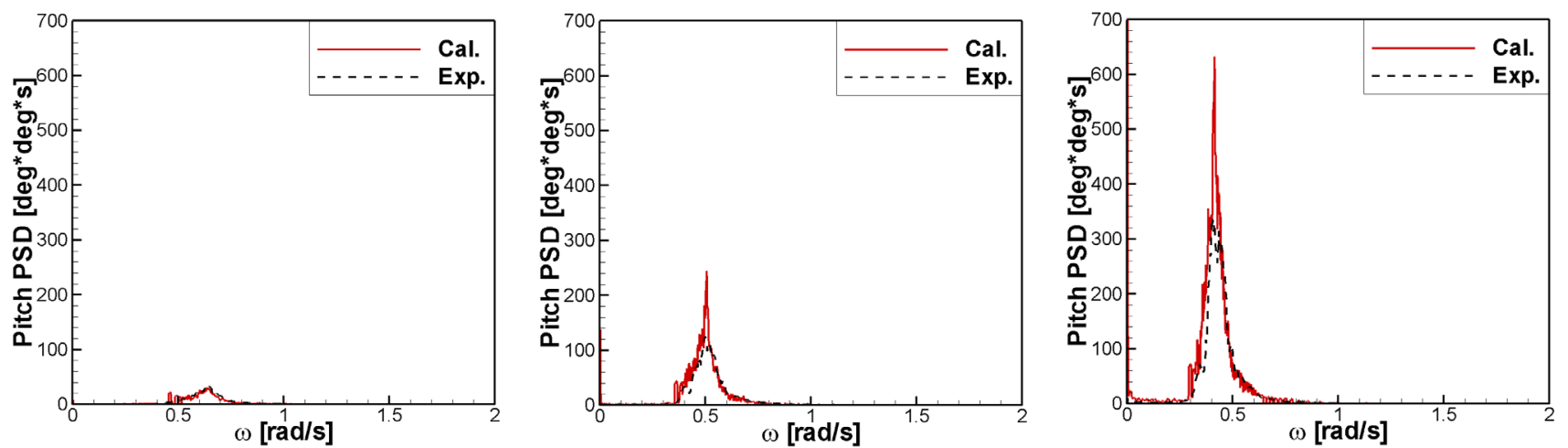

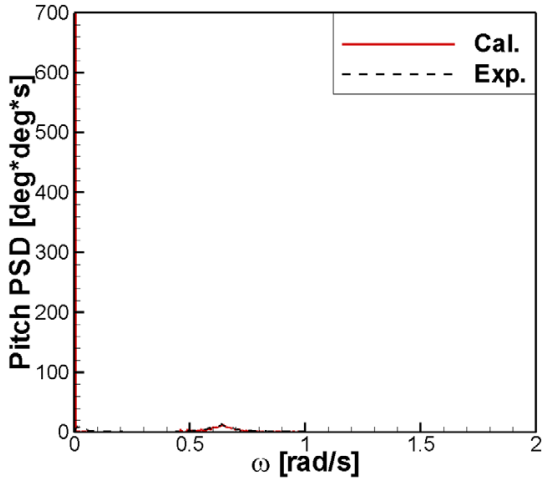

(a) Sea state 5

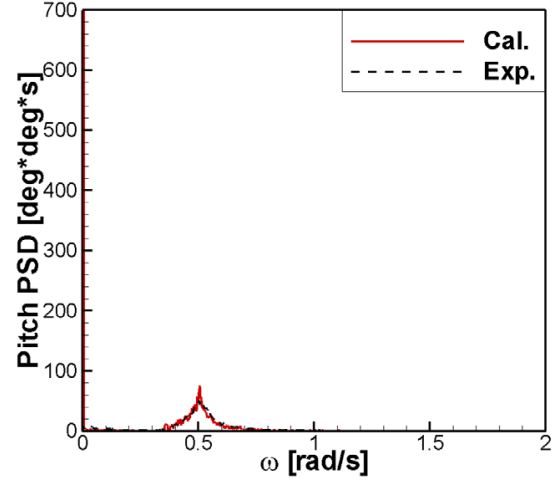

(b) Sea state 6

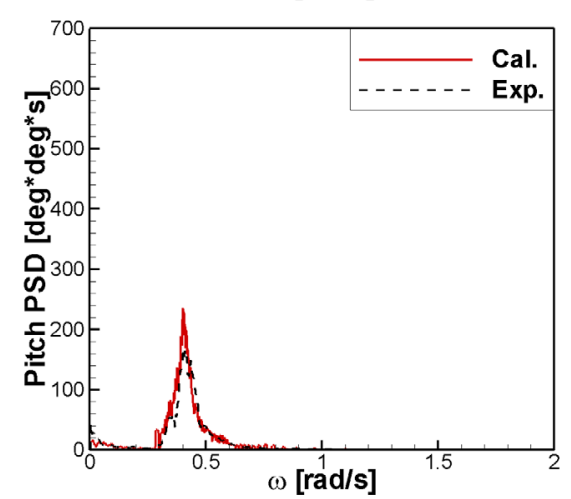

(c) Sea state 7

Fig. 7 Comparison of motion response spectra (upper : wave only, lower : combined environment)

종동요 운동의 주파수 응답 특성을 분석하기 위하여 운동 응 답 스펙트럼(Motion response spectrum)을 검토하였다. Fig. 7은 시계열을 푸리에 변화(Fourier transformation)를 한 운동 응답 스 펙트럼이다. 모형시험 결과 검토를 위해 수치 시뮬레이션 결과 를 함께 도시하였다. 앞선 시계열에서의 관찰과 동일하게, 해상 상태가 증가할수록 부이 구조물의 종동요 응답 스펙트럼도 크
게 증가하는 경향을 보여주고 있다. 이 때 운동 응답 스펙트럼 의 정점주기도 파도 스펙트럼과 유사하게 점차 장주기(저주파 수)쪽으로 이동하였다. 복합 환경 조건에서는 종동요 응답 스펙 트럼이 파도 단독 조건에 비하여 상당히 줄어든 것을 확인할 수 있다. 이는 조류 및 바람에 의한 부가적인 감쇠력으로 인하 여 부이 구조물이 종동요가 상대적으로 저감했기 때문으로 사 


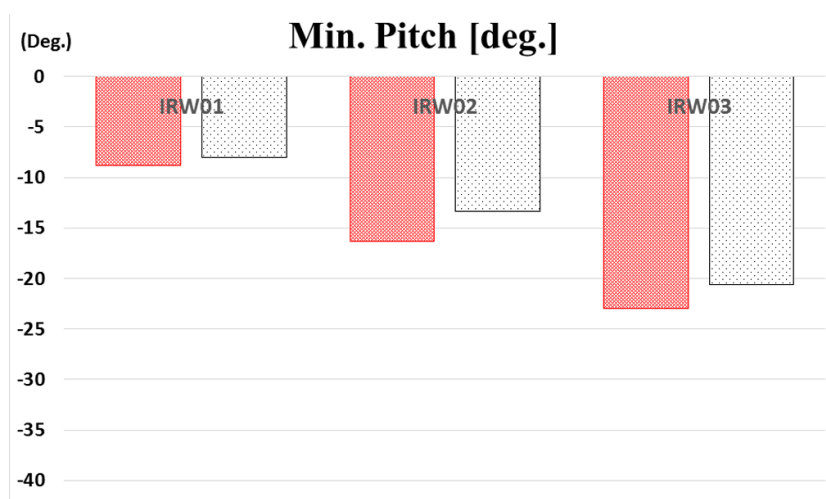

Cal. Exp.

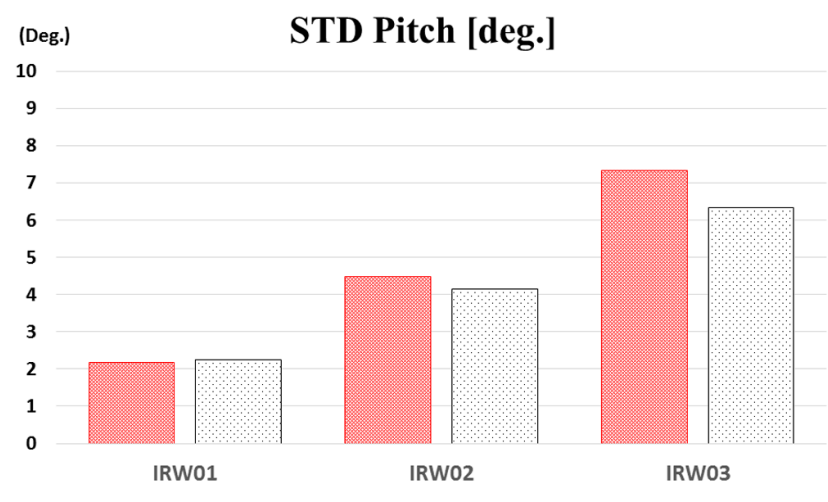

(a) Wave only

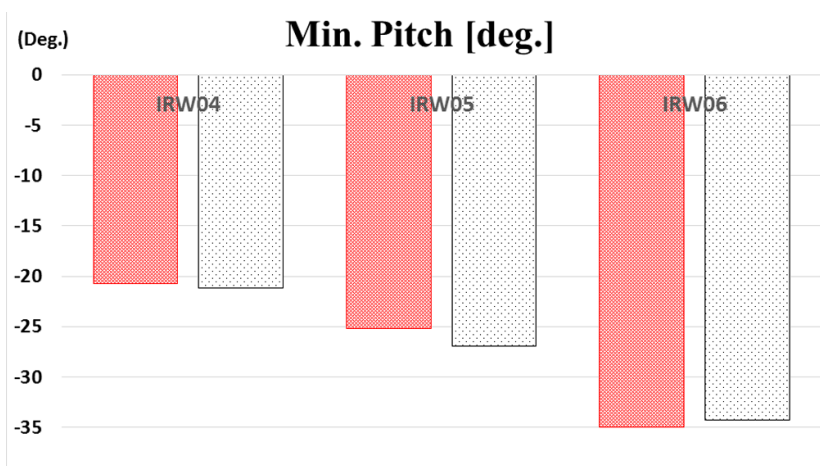

Cal. Exp.

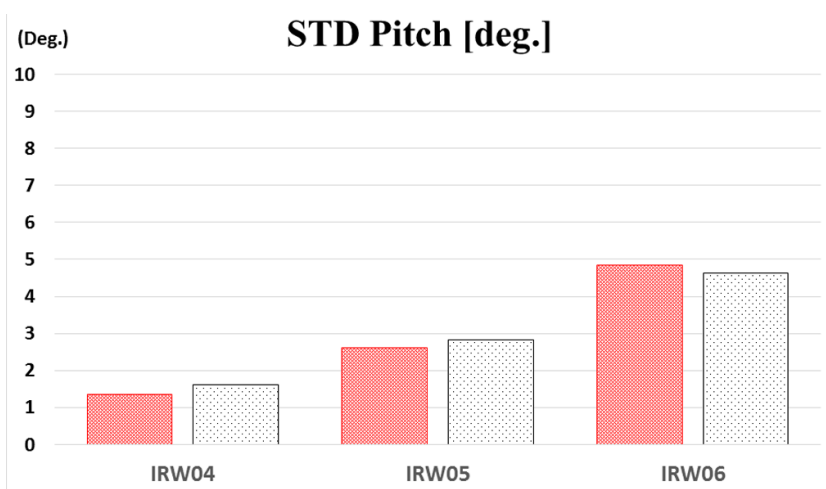

Cal. $\square$ Exp.

(b) Combined environment

Fig. 8 Comparisons of motion statistics of pitch motion of the buoy

료된다. 모형시험과 수치 시뮬레이션 결과를 직접 비교하면, 정 점주기 근방에서 수치시뮬레이션 결과가 다소 크게 평가 되었 지만 전반적으로는 모형시험과 수치해석 결과는 서로 잘 일치 하는 경향을 보인다. 두 결과사이의 차이는 입사파 에너지와 감 쇠력 모델의 차이로부터 발생한 것으로 판단된다.

Fig. 8은 부이 구조물 종동요의 최소값과 표준편차를 비교하 여 보여주고 있다. 해상상태가 높아질수록 종동요의 최소값과 표준편차 값이 모두 증가하는 경향을 보였다. 복합 환경조건에 서는 조류와 바람에 의한 정적 경사 각도로 인하여 파도 단독 인 조건에 비하여 부이 구조물의 최소 종동요가 더 크게 발생 한 것을 확인할 수 있다. 해상상태 7 조건을 기준으로 보면 부 이 구조물의 최소 종동요 값은 파도 단독 조건에서 $-22^{\circ}$ 이지만, 복합 환경 조건에서 $-35^{\circ}$ 까지 발생하였다. 반면 종동요의 표준
편차 값은 파도 단독 조건에 비하여 복합 환경 조건에서 약 $18 \%-25 \%$ 가량 줄어든 것을 확인할 수 있다. 수치 시뮬레이션 결과는 모형시험결과보다 부이 구조물을 종동요를 다소 과대평 가하고 있지만, 전반적으로 경향은 잘 일치하는 것을 확인할 수 있다.

\section{2 상부구조물 침수여부(횟수)}

본 부이 구조물은 파도에 의한 종동요 응답으로 인해 침수에 취약할 수 있다. 특히 고조위(HAT) 조건에서 조류 및 바람에 의 해 정적 경사각이 크게 발생한 상황에서는 부이 구조물의 침수 는 빈번하게 발생할 가능성이 높다. 부이 구조물 상부에는 여러 장비가 탑재되기 때문에, 이러한 침수 여부와 빈도수는 본 부이 구조물의 성능과 관련된 중요한 인자가 된다. Fig. 9는 해상 상
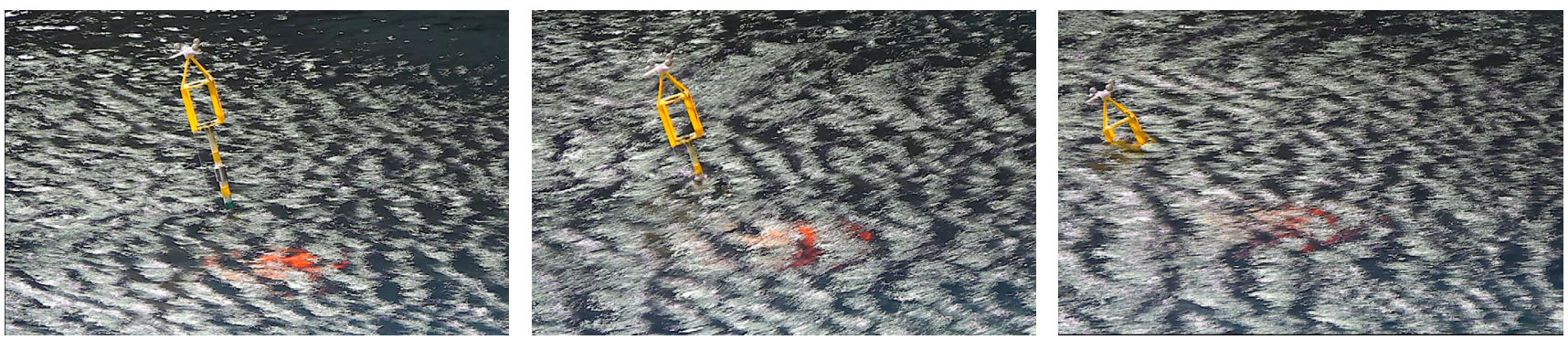

Fig. 9 Snapshots on submergence of a equipment 

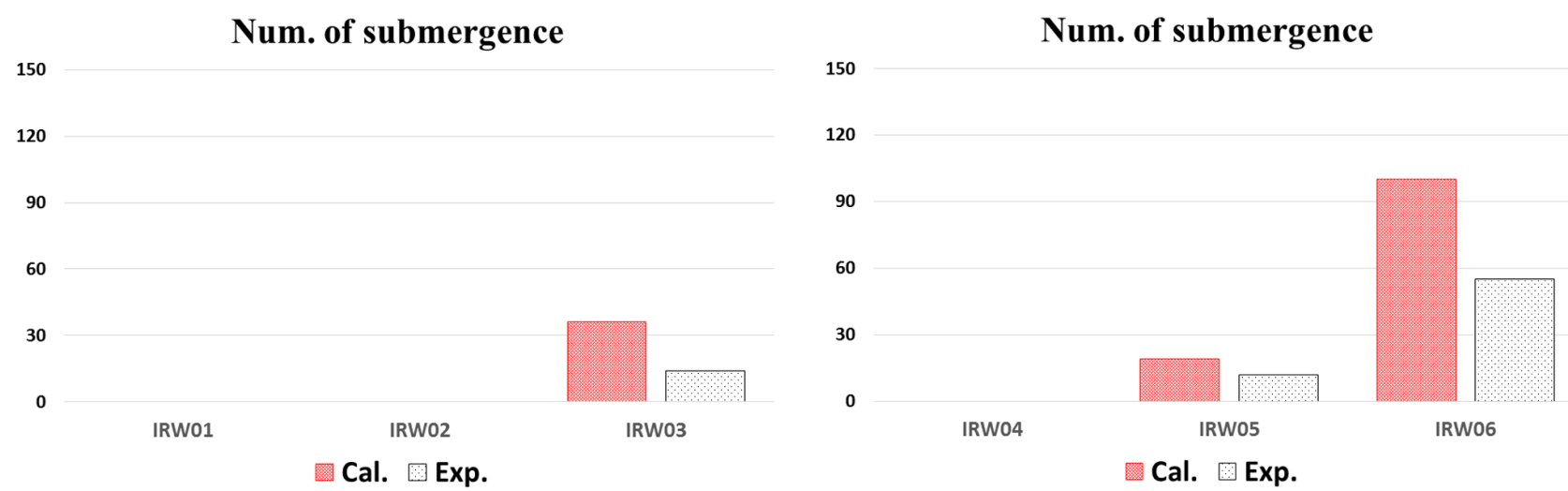

Cal. Exp.

$\square$ Cal. Exp.

Fig. 10 Comparisons of number of submergence per hour (left : wave only, right : combined environment)

태 7의 복합 환경 조건에서 상부 구조물의 일련의 침수 모습을 보여준다. 조류, 바람과 더불어 높은 파랑 조건에서 구조물의 종동요로 인하여 상부 구조물이 완전 침수되는 모습을 확인할 수 있다.

Fig. 10은 해상 상태에 따른 상부 구조물의 시간당 침수 횟수 를 비교하여 보여준다. 파도 단독 조건에서 유의파고 $3.25 \mathrm{~m}$ (IRW01)과 5.0m(IRW02) 까지는 침수가 발생하지 않았지만, 유 의파고 $8 \mathrm{~m}$ (IRW03)에서는 침수가 발생하였다. 이는 수치 시뮬레 이션에서도 동일하게 확인되었다. 다만 앞 절에서 설명한 바와 같이 수치 시뮬레이션이 더 큰 종동요 응답 결과를 주고 있기 때문에, 침수 빈도수도 수치 시뮬레이션이 모형시험보다 훨씬 더 높게 평가된다. 복합 환경 조건에서는 조류 및 바람에 의한 초기 경사각으로 인하여 상대적으로 더 낮은 해상상태인 해상 상태 6 조건에서부터 침수가 발생하였다. 모형시험 평가 결과를 보면 해상상태 6 조건에서의 침수 빈도수는 시간당 약 12 회였으 며, 해상 상태 7조건에서는 단위 시간당 약 55회의 침수가 발생 하였다. 이 경우에도 수치 시뮬레이션은 1.5 2 배가량 침수 빈
도수가 큰 결과를 제시하고 있다. 이는 수치 감쇠 모델의 차이 로 인하여 부이 구조물의 종동요가 다소 크게 시뮬레이션이 되 었고, 그 결과 침도 빈도수가 증가한 것으로 사료된다. 모형시 험과 수치 시뮬레이션 모두 본 부이 구조물은 해상 상태 6이상 의 조건에서는 침수가 발생하는 것으로 평가하고 있기 때문에, 이러한 침수 여부를 고려하여 상부에 탑재되는 장비의 방수성 능 또는 운용기간을 검토할 필요가 있다.

\section{3 앵커 지지력}

본 부이 구조물은 하부의 중력식 앵커에 의해 지지된다. 일반 적으로 생존 조건에서의 앵커에 작용하는 최대 하중을 고려하 여 앵커 용량을 산정하게 된다. 따라서 본 연구에서는 부이 구 조물 하단 힌지 연결부에 1축 로드셀을 설치하여, 앵커 지지력 (Anchor reaction force)을 평가하였다. Fig. 11은 해상상태에 따 라 파도 단독 조건(좌측)과 복합 환경 조건(우측)에서의 앵커 지 지력 시계열을 보여준다. 이때 시계열은 앵커 지지력의 초기 하 중을 제외한 동적 하중만을 나타내고 있다. 본 조건에서 앵커에
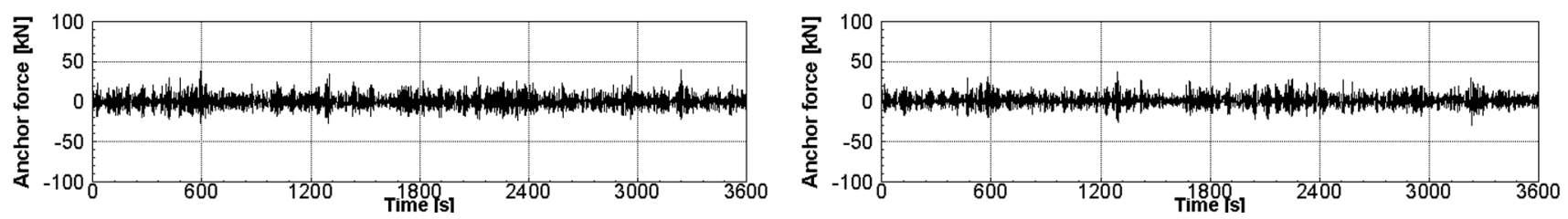

(a) Sea state 5
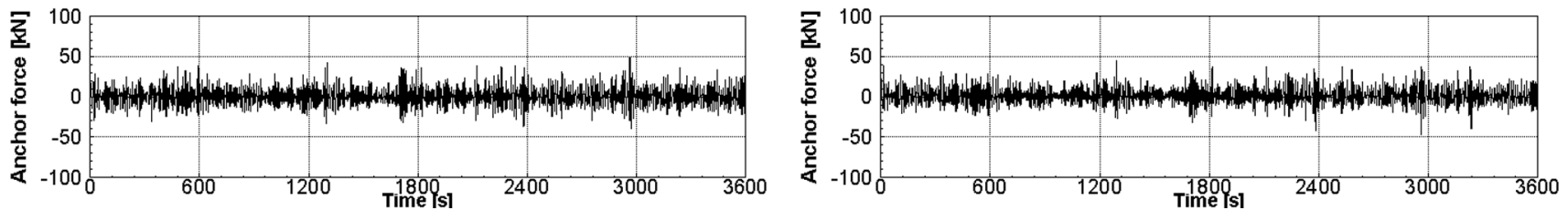

(b) Sea state 6
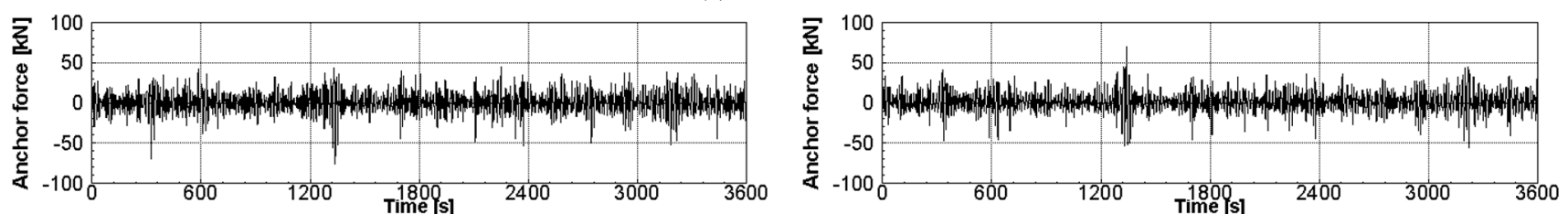

(c) Sea state 7

Fig. 11 Time series of anchor reaction force of the buoy (left: wave only, right: combined environment) 

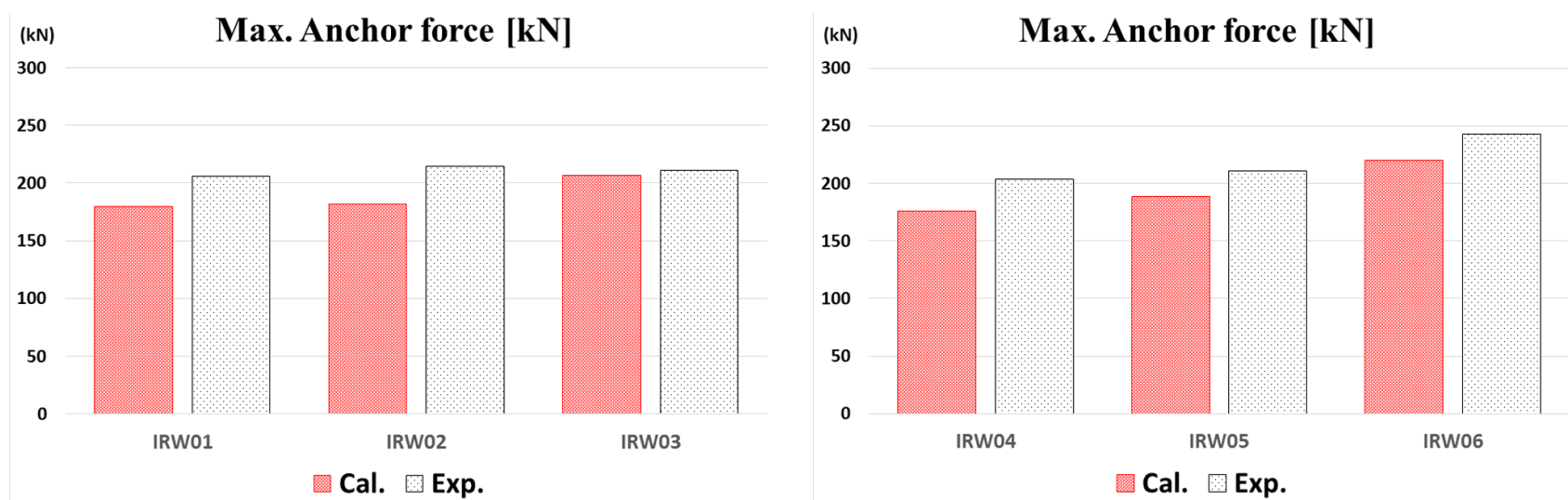

Fig. 12 Comparisons of maximum anchor force (left: wave only, right: combined environment)

작용하는 초기 정적 하중은 $165.8 \mathrm{kN}$ 이다. 전반적으로 해상상태 가 높아짐에 따라 앵커 지지력이 증가하는 경향을 보인다. 이는 종동요 운동과 입사파의 파고 변화로부터 부이 구조물에 작용 하는 동적 하중이 해상상태가 높아질수록 증가하기 때문이다.

Fig. 12는 계산과 실험에서 앵커 지지력의 최대값을 비교하여 보여준다. 앞서 살핀 바와 같이 앵커 지지력은 해상 상태가 높 아짐에 따라 증가하는 경향을 보이며, 모형시험 결과가 수치해 석 보다 5 20\% 가량 큰 앵커 하중을 평가한다. 이는 축척효과 (Scale effect)에 의한 유체항력의 증가와 수심조건의 차이로 인 한 앵커 하중 증가로 사료된다. 해상 상태 7에서의 최대 앵커 지지력은 약 25 톤이였다. 이는 정적 앵커 하중을 기준으로 약 1.48 배에 해당한다.

\section{5. 결 론}

본 연구에서는 긴 파이프와 부력재로 구성된 세장형 아티큘 레이티드 타워 형태의 부이 구조물에 대해 황천 조건에서의 생 존성을 모형시험 연구를 통하여 평가하였다. 3 가지 해상 상태에 서의 부이 구조물의 성능을 평가하였으며, 비교를 위해 수치 시 뮬레이션 결과를 같이 비교 분석하였다. 일련의 모형시험 평가 를 통하여 다음과 같은 결론을 얻을 수 있었다.

(1) 본 부이 구조물은 앵커 연결점을 중심으로 힌지 운동을 하기 때문에 매우 큰 종동요 운동 특성을 보여주고 있으며, 특 히 해상상태 7의 복합 환경 조건에서는 조류 및 바람의 정적 경 사 각도로 인하여 최소 -35 도까지 종동요가 발생할 수 있음을 확인하였다.

(2) 큰 종동요 운동으로 인하여 부이의 상부 구조물은 침수의 위험에 노출되며, 복합 환경 조건을 기준으로 해상상태 6 부터는 침수가 발생하는 것으로 평가되었다. 특히 해상 상태 7 조건에 서는 시간당 약 50 회 이상의 잦은 침수에 노출되는 것으로 평 가되었다. 이러한 침수 가능성을 고려하여 상부에 탑재되는 장 비의 방수 성능 및 운용 기간을 검토할 필요가 있다.
(3) 앵커 용량과 관련하여 앵커 지지력을 계측하였으며, 해상 상태 7에서 최대 앵커 지지력이 정적 앵커 하중 대비 약 1.48 배 가량 발생할 수 있음을 확인하였다. 이러한 앵커 지지력과 안전 율을 고려하여 앵커의 최종 용량이 산정될 필요가 있다.

$$
\text { 후기 }
$$

본 연구는 한국지질자원연구원의 지원을 받아 수행하는 ‘수중 고주파수 음파계측모듈 개발 및 수중음파 신호 해석'(PNS3390) 과제의 연구결과 중 일부임을 밝힙니다.

\section{References}

Berteanx, H.O., 1976. Buoy Engineering. Woods Hole Oceanographic Institution.

Carpenter, E.B., Leonard, J.W., Yim, S.C.S., 1995. Experimental and Numerical Investigations of Tetherd Spar and Sphere Buoys in Irregular Waves. Ocean Engineering, 22(8), 765-784. https:// doi.org/10.1016/0029-8018(95)00016-E

Ma, C., Iijima, K., Fujikubo, M., 2015. Sub-harmonic Motion of a Buoy Tethered to Seabed. Proceedings of the 25th International Offshore and Polar Engineering Conference, Hawaii USA, 316-323.

Lee, G.H., Kim, I.O., Cha, B.J., Jung. S.J., 2014. Difference of Tension on Mooring Line by Buoy Type. Journal of the Korean Society of Fisheries Technology, 50(3), 233-243. https://doi.org/ 10.3796/KSFT.2014.50.3.233

Park, H.I., Shin, M.G., 2003. Characteristic Analysis of Ocean Observation Buoys for Application to Seas around Korea Peninsula. Proceedings of the Korean Society for Marine Environment and Energy, 267-273. 